\title{
Coliform density in oyster culture waters and its relationship with environmental factors
}

\author{
Luciene Mignani(1), Edison Barbieri(2), Helcio Luis de Almeida Marques(2), \\ Ana Julia Fernandes Cardoso de Oliveira ${ }^{(3)}$
}

(1)Ministério da Pesca e Aquicultura, SBS, Quadra 2, Lote 10, Bloco J, 8o andar, CEP 70070-120 Brasília, DF, Brazil. E-mail: lucienemignani@yahoo.com.br (2)Instituto de Pesca, Agência Paulista de Tecnologia dos Agronegócios, Avenida Prof. Besnard s/no , CEP 11990-000 Cananéia, SP, Brazil. E-mail: edisonbarbieri@yahoo.com.br, hlamarques@gmail.com (3)Universidade Estadual Paulista Júlio de Mesquita Filho, Campus Experimental do Litoral Paulista, Praça Infante Dom Henrique, s/no, CEP 11330-900 São Vicente, SP, Brazil. E-mail: ajulia@gmail.com

\begin{abstract}
The objective of this work was to evaluate the total and thermotolerant coliform densities in the oyster culture water of Cananeia, SP, Brazil, correlating these densities with environmental variables and tidal variations. Superficial water samples were collected in two tide conditions (spring and neap) from three areas of Cananéia municipality (Mandira, Itapitangui and Cooperostra). The three studied areas showed good conditions for the culture regarding coliform densities. The two tidal conditions differed significantly as to total coliform concentration; however, the same procedure was not performed for thermotolerant coliforms. No correlation was observed between water temperature, $\mathrm{pH}$, and concentrations of total and thermotolerant coliforms. Coliform density was positively correlated with rainfall and negatively correlated with salinity. Spring and neap tides differed significantly as to coliform number. Simple diagnosis of environmental conditions of the crop fields is insufficient to assess water quality of shellfish cultivation. A continuous monitoring program of planted areas is necessary both for the assessment of water quality potential for marine culture and for ensuring safe consumption of seafood, besides constituting an important tool to understand the relationships between contamination and the involved environmental variables.
\end{abstract}

Index terms: Crassostrea, contamination, microbiology, principal component analysis, total and thermotolerant coliforms.

\section{Densidade de coliformes em águas de cultivo de ostras e sua relação com fatores ambientais}

Resumo - O objetivo deste trabalho foi avaliar as densidades de coliformes totais e termotolerantes, em água de cultivo de ostra de Cananeia, SP, e correlacionar estas densidades com variáveis ambientais e as variações das marés. Foram coletadas amostras de água superficial em duas condições de maré (sizígia e quadratura) de três áreas do Município de Cananéia (Mandira, Itapitangui e Cooperostra). As três áreas estudadas apresentaram boas condições para cultivo, quanto à densidade de coliformes. Diferenças significativas foram registradas entre as condições de marés quanto à concentração total de coliformes; no entanto, o mesmo procedimento não se aplicou para coliformes termotolerantes. Nenhuma correlação foi observada entre a temperatura da água, o pH e as concentrações de coliformes total e termotolerantes. As densidades de coliformes correlacionaram-se positivamente com a pluviosidade e negativamente com a salinidade. O número de coliformes foi significativamente diferente nas marés de sizígia e de quadratura. O simples diagnóstico das condições ambientais é insuficiente para avaliar a qualidade da água de cultivo de ostras. Um programa de monitoramento contínuo de áreas cultivadas é necessário tanto para avaliar o potencial dessas águas, como para garantir o consumo seguro de frutos do mar, além de constituir-se como instrumento importante para a compreensão das relações entre a contaminação por coliformes e as variáveis ambientais envolvidas.

Termos para indexação: Crassostrea, contaminação, microbiologia, análise de componentes principais, colifirmes totais e termotolerantes.

\section{Introduction}

The potential use of coastal waters for the cultivation of bivalves can be threatened by contamination because, as filter organisms, they are able to concentrate high densities of chemicals and microorganisms from the aquatic environment (Dame, 1996), including those responsible for waterborne diseases.

Diseases of the highest incidence are those of the gastrointestinal tract, associated with consumption of contaminated fish and seafood. Patients may show more serious infections such as gastroenteritis, hepatitis A, 
cholera and typhoid fever, and other diseases caused by opportunistic pathogens (World Health Organization, 1998). Therefore, water sanitary quality, where bivalve mollusks are grown, is directly responsible for public health problems, which may arise when these foods are consumed, especially if eaten fresh (Santos, 1982), as is the case with oysters.

To assess the sanitary conditions of a particular location, it is necessary to adopt parameters and criteria, among which are the indicators of fecal pollution in the aquatic environment, especially thermotolerant coliforms (American Public Health Association, 2005), because the presence of microbiological indicators of fecal contamination can indicate recent or more remote pollution (Efstratiou, 2001).

Resolution 357/2005 of the Conselho Nacional do Meio Ambiente (Conama), the Brazilian Ministry for the Environment, established standards for the brackish water of class 1 , suitable for the activities of aquaculture and fisheries, providing that for bivalve culture intended for human consumption, regarding the density of thermotolerant coliforms, a minimum of 15 samples should not exceed 43 of the most probable number of coliforms (MPN) $100 \mathrm{~mL}^{-1}$, and $90 \%$ should not exceed 88 of the MPN $100 \mathrm{~mL}^{-1}$. According to the same resolution, these rates should be the same in annual monitoring with a minimum of five samples.

Correlating concentrations of total and thermotolerant coliforms, in the culture water of Crassostrea brasiliana (Lam. 1819), in Cananeia, SP, Brazil, with some environmental variables and the variations of the tide, is a contribution to reduce risks associated with consumption of mollusks, especially oysters, from the region.

The objective of this work was to evaluate the total and thermotolerant coliform densities in the oyster culture water of Cananeia, SP, Brazil, correlating these densities with environmental variables and tidal variations.

\section{Materials and Methods}

Cananeia estuarine-lagoon complex is located in the south of São Paulo state, Brazil, and is associated with an extensive mangrove within the Iguape-Cananeia Protection Area. This area is responsible for most of the production of the native oyster (Crassostrea brasiliana), in São Paulo, which is the main natural resource produced by the local community (Ristori et al., 2007). Due to environmental and economic importance of oysters in the region, it is necessary to understand the fluctuations of the sanitary quality of water, especially in areas used for growing oysters.

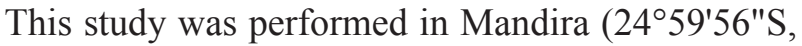
$\left.48^{\circ} 01^{\prime} 11^{\prime \prime} \mathrm{W}\right)$, Itapitangui $\left(24^{\circ} 58^{\prime} 20^{\prime \prime} \mathrm{N}, 4^{\circ} 59^{\prime} 00^{\prime \prime} \mathrm{W}\right)$ and Cooperostra $\left(24^{\circ} 57^{\prime} 43^{\prime \prime} \mathrm{N}, 4^{\circ} 54^{\prime} 38^{\prime \prime} \mathrm{W}\right)$, in the Cananeia estuary (Figure 1). Mandira is the largest oyster cultivation area, while Itapitangui has the greater risk of contamination.

In Mandira and Itapitangui, samples were collected between March 2007 and February 2008 (12 samples), and in Cooperostra the sample period was from April 2007 to September 2008, (17 samples). Samples were always collected in the morning and were taken every two weeks alternating monthly between tides. Neap tide is a minimum range tide occurring at the first and the third quarters of the moon. Spring tide is a greater-than-average tide between the high and low tides that occur twice each synodic month around the times of new and full moon.

Sampling points in each area were determined during preliminary sampling, according to the proximity and extension of the study areas. In each area, temperature, salinity and $\mathrm{pH}$ of water were determined in loco, using a multiparameter measuring equipment model 63, (YSI Incorporated, Yellow Springs, Ohio, USA). Rainfall data were obtained from a Universidade de

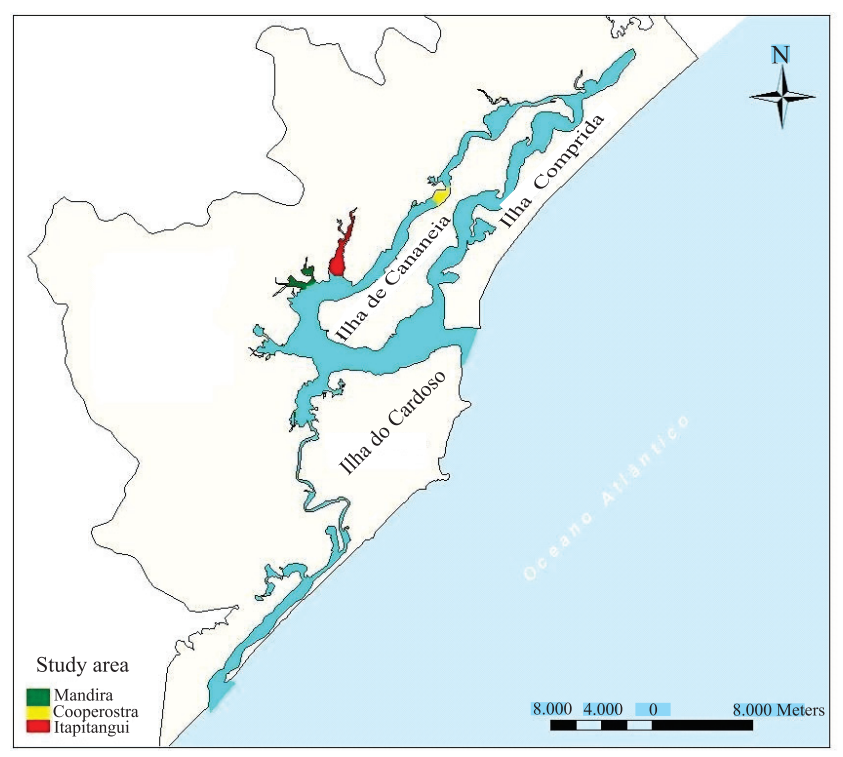

Figure 1. Cananeia, SP, Brazil, study areas in the Cananeia Estuary. 
São Paulo meteorological station located in Cananeia. Rainfall utilized records corresponded to the average rainfall in the four days preceding the sampling date.

Water samples were manually collected in counterflow (from 15 to $30 \mathrm{~cm}$ depth), in sterile flasks and were kept under refrigeration, during transportation for analysis in the laboratory of the Instituto Adolfo Lutz, located $50 \mathrm{~km}$ from Cananeia. The microbiological analyses were carried out at a maximum of six hours after field sampling. Sampling, packaging and transport followed the recommendations of the standard methods for the examination of water and waste water (American Public Health Association, 2005).

The densities of total and thermotolerant coliforms in the water samples were determined using the multiple tube test (American Public Health Association, 2005). In the present study, inocula were used in three fold dilutions, in sets of five tubes. In the first series, the tubes containing $9 \mathrm{~mL}$ of culture medium at a double concentration were inoculated with $10 \mathrm{~mL}$ of sample (dilution 10); in the second series of tubes $1 \mathrm{~mL}$ of the samples was inoculated (dilution 1); and the third series of tubes were inoculated with $0.1 \mathrm{~mL}$ of the samples (dilution 0.1). The second and third sets of tubes contained $9.0 \mathrm{~mL}$ of culture medium in a simple concentration.

For the coliform test, the culture medium used was L-lauryl sulfate sodium broth (LSSB). The samples were incubated at $35 \pm 1^{\circ} \mathrm{C}$ for $24-48$ hours. Tubes that showed acid and gas production were presumed positive for coliforms.

For confirmation of total coliforms, growth from the presumptive, positive test tubes were transferred to tubes containing $9 \mathrm{~mL}$ of brilliant green bile $2 \%$ lactose broth (BGBLB), and incubated at $35 \pm 1^{\circ} \mathrm{C}$ for 48 hours. For confirmation of thermotolerant coliforms, growth from presumptive, positive test tubes from the LSSB and BGBLB broths were transferred to tubes with Escherichia coli Broth (EC Broth) and incubated in water bath at $44 \pm 0.2^{\circ} \mathrm{C}$ for 48 hours. After incubation, the presence of acid and gas was considered positive for thermotolerant coliforms.

The densities of coliform bacteria in the samples were obtained from the MPN table, based on the number of positive tubes in each dilution of the confirmed tests (American Public Health Association, 2005). The results were expressed as MPN of coliforms in $100 \mathrm{~mL}^{-1}$ of sample (MPN $100 \mathrm{~mL}^{-1}$ ).
To determine the normality and homogeneity of data, the Shapiro-Wilk test (Zar, 2009) was used. Correlation between parameters was evaluated using the Spearman linear correlation (Zar, 2009). The nonparametric Kolmogorov-Smirnov (Zar, 2009) test was used to correlate microbiological concentrations with tidal changes. The same test was used to compare microbiological densities in the three study areas. Through the principal component analysis (PCA), the microbiological and environmental data were correlated with each other and also with the tides at a $5 \%$ probability.

Table 1. Geometric means, minimum and maximum values of total and thermotolerant coliform densities (MPN 100 $\mathrm{mL}^{-1}$ ) in Mandira, Itapitangui and Cooperostra. Cananeia, SP, Brazil, 2007-2008.

\begin{tabular}{lccc}
\hline Coliforms & Minimum & $\begin{array}{c}\text { Maximum } \\
\text { Total }\end{array}$ & Geometric mean \\
Thermotolerant & 7 & 170 & 18 \\
\hline \multirow{3}{*}{ Total } & 2 & 130 & 9 \\
Thermotolerant & 17 & 1,600 & 156 \\
\hline \multirow{3}{*}{ Itapitangui } \\
Total & 4 & 1,600 & 38 \\
Thermotolerant & 0 & Cooperostra \\
\hline & 0 & 1,600 & 48 \\
\hline
\end{tabular}

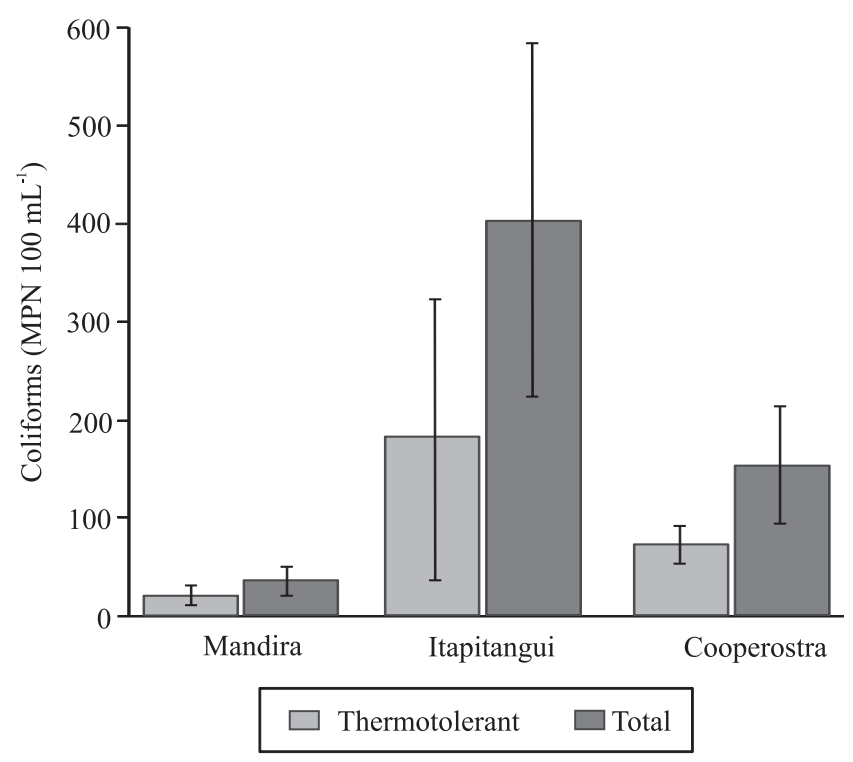

Figure 2. Geometric means of coliforms (MPN $\left.100 \mathrm{~mL}^{-1}\right)$ in the study areas. Cananeia, SP, Brazil, 2007-2008.

Pesq. agropec. bras., Brasília, v.48, n.8, p.833-840, ago. 2013 DOI: $10.1590 / \mathrm{S} 0100-204 \mathrm{X} 2013000800004$ 


\section{Results and Discussion}

The lowest geometric means of total and thermotolerant coliforms occurred in Mandira. The highest levels of total and thermotolerant coliforms were observed at Itapitangui. In Cooperostra, coliform levels were intermediate, in comparison the those of Mandira and Itapitangui (Table 1).

The Kolmogorov-Smirnov test showed no significant differences between Mandira, Itapitangui and Cooperostra $(p<0.05)$, for the concentration of thermotolerant coliforms $(\mathrm{P}=0.0001)$. However, for total coliforms, there was a significant difference between Mandira and Itapitangui $(\mathrm{p}=0.01)$ (Figure 2).

Itapitangui showed values during April (80 MPN $100 \mathrm{~mL}^{-1}$ ), May (130 MPN $100 \mathrm{~mL}^{-1}$ ), October (55 MPN $100 \mathrm{~mL}^{-1}$ ) and November (1.600 MPN $100 \mathrm{~mL}^{-1}$ ) that exceeded 43 thermotolerant coliforms per $100 \mathrm{~mL}$, allowable limits by Conama 357/2005. Samples from Mandira showed coliforms above the tolerable values in December (130 MPN $\left.100 \mathrm{~mL}^{-1}\right)$, while Cooperostra samples of August (300 MPN $\left.100 \mathrm{~mL}^{-1}\right)$, January (90 MPN $\left.100 \mathrm{~mL}^{-1}\right)$, March (300 MPN $\left.100 \mathrm{~mL}^{-1}\right)$, April (80 MPN $100 \mathrm{~mL}^{-1}$ ) and September (170 MPN $100 \mathrm{~mL}^{-1}$ ) exceeded the acceptable limits.

Many factors can influence the survival of microorganisms in estuarine ecosystems, mainly depending on environmental conditions, including tides. Tidal variations influence incisively in water contamination because, during high tides, sea water acts as a barrier to contaminated water courses, while at low tide there is drainage of surface water into the sea. The results obtained indicate a significant influence of tides on the concentration of total $(\mathrm{p}=0.0001)$ coliforms, but no significant difference for thermotolerant coliforms $(\mathrm{p}=0.1)$.

During the neap tide (a minimum range tide occurring at the first and the third quarters of the moon), averages of total and thermotolerant coliforms, grouped for the three areas, were $53 \mathrm{MPN} 100 \mathrm{~mL}^{-1}$ and $18 \mathrm{MPN} 100 \mathrm{~mL}^{-1}$, respectively, whereas in the spring tide (a greater-than-average tide between the high and low tides that occur twice each synodic month around the times of new and full moon), the averages were $44 \mathrm{MPN} 100 \mathrm{~mL}^{-1}$ for total and $22 \mathrm{MPN} 100 \mathrm{~mL}^{-1}$ for thermotolerant coliforms. The highest geometric means of total and thermotolerant coliforms were recorded during the neap tide at Mandira and Itapitangui (170 MPN $100 \mathrm{~mL}^{-1}$ and 1,600 MPN $100 \mathrm{~mL}^{-1}$, respectively), while Cooperostra showed the highest average during the spring tide (1,600 MPN $\left.100 \mathrm{~mL}^{-1}\right)$. This is possibly due to the constant water flow during the tidal cycle in the Cooperostra-growing area. Kolm \& Andretta (2003) studied the bacterial contamination of Perequê's stream, in Pontal do Sul, PR, Brazil, and found a direct relationship between tides and coliform concentration, with highest values during low tide in July. However, this period was characterized by high precipitation, which may also have influenced the concentration.

A significant Kolmogorov-Smirnov difference $(p<0.05)$ between neap and spring tides $(p=0.0001)$ was found. Thermotolerant coliform analyses showed no significant differences between neap and spring tides $(p=0.1)$ for any of the sampling areas.

The geometric means of total coliforms (Figure 3) were higher during the summer (279 MPN $100 \mathrm{~mL}^{-1}$ ) and autumn (70 MPN $100 \mathrm{~mL}^{-1}$ ), increasing during winter (209 MPN $100 \mathrm{~mL}^{-1}$ ) and spring (210 MPN $\left.100 \mathrm{~mL}^{-1}\right)$. Thermotolerant coliforms had the highest average in spring (206 MPN $\left.100 \mathrm{~mL}^{-1}\right)$, followed by summer (79 MPN $100 \mathrm{~mL}^{-1}$ ), autumn (43 MPN $\left.100 \mathrm{~mL}^{-1}\right)$ and winter $\left(50 \mathrm{MPN} 100 \mathrm{~mL}^{-1}\right)$. There was no significant differences between seasons and coliform levels for both total $(\mathrm{p}=0.87)$ and thermotolerant coliforms $(p=0.42)$.

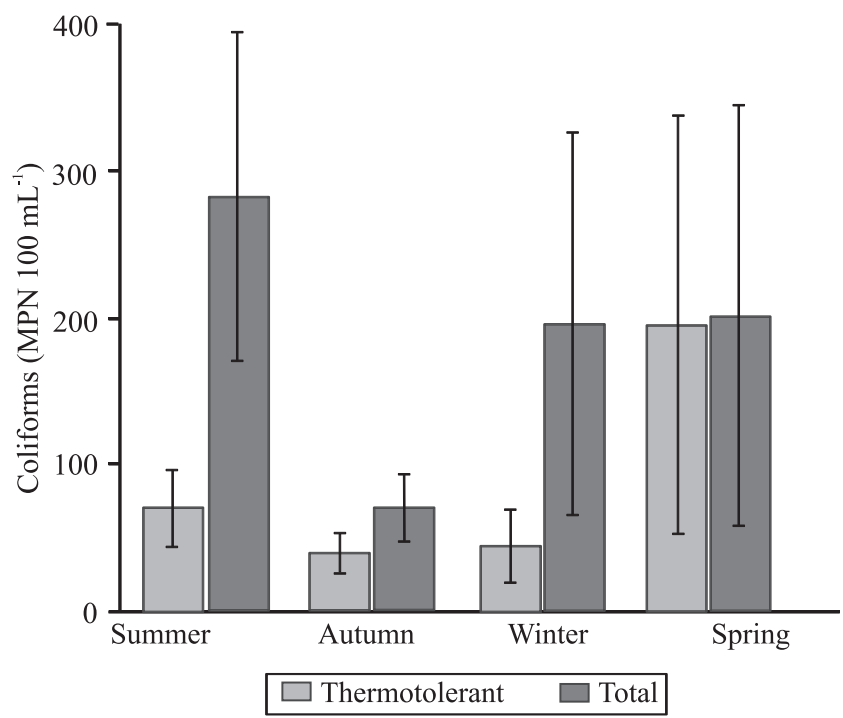

Figure 3. Seasonal variation of coliform densities in the study areas. Cananeia, SP, Brazil, 2007-2008. 
The lowest temperature was $17.0^{\circ} \mathrm{C}$ recorded for Itapitangui, in August, while the highest temperature was $28.4^{\circ} \mathrm{C}$, recorded for February in Cooperostra. According to the Spearman simple linear correlation analysis, there was no correlation between water temperature and concentrations of total and thermotolerant coliforms $(\mathrm{r}=0.08$ for total, and $r=-0.006$ for thermotolerant) (Table 2 ). This is possibly due to an insufficient range of water temperature variation (Tommasi, 1979).

Salinity ranged from 0.2 (November, Itapitangui) and 25.4 (August, Cooperostra) in the different seasons, during the sample period (Table 2). There was

Table 2. Linear correlation coefficient of total and thermotolerant coliforms with environmental variables (temperature, rainfall, salinity and $\mathrm{pH}$ ). Cananeia, Brazil, 2007-2008.

\begin{tabular}{lccc}
\hline Variable & $\mathrm{r}$ & $\mathrm{T}(\mathrm{N}-2)$ & $\mathrm{P}(<0,05)$ \\
\hline \multirow{4}{*}{ Thermotolerant coliforms } & 0,88 & 11,77 & 0,00 \\
Temperature & 0,08 & 0,41 & 0,67 \\
Rainfall & 0,36 & 2,41 & 0,02 \\
Salinity & $-0,35$ & $-2,55$ & 0,01 \\
pH & 0,19 & 1,00 & 0,32 \\
\hline \multicolumn{4}{c}{ Thermotolerant coliforms } \\
Temperature & 0,006 & 0,69 & \\
Rainfall & 0,28 & 1,86 & 0,49 \\
Salinity & $-0,40$ & $-2,91$ & 0,05 \\
pH & 0,09 & 0,90 & 0,04 \\
\hline & Temperature & 0,37 \\
Rainfall & 0,44 & 3,02 & \\
Salinity & $-0,32$ & $-2,11$ & 0,004 \\
pH & $-0,36$ & $-2,41$ & 0,041 \\
\hline
\end{tabular}

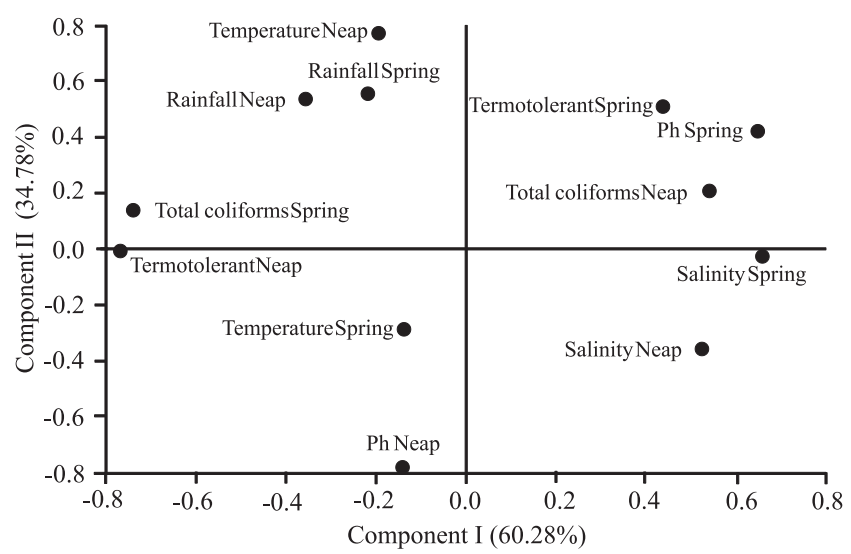

Figure 4. Linear correlation of the principal component analysis (PCA) between the environmental data, total and thermotolerant coliform densities, and tides (neap and spring). Cananeia, SP, Brazil, 2007-2008. a negative correlation (Spearman) between salinity and the total $(r=-0.35)$ and thermotolerant $(r=-0.40)$ coliform levels.

During the sample period, $\mathrm{pH}$ ranged from 5.89 (Cooperostra in September) to 8.26 (September, Cooperostra). No correlation (Spearman) with the concentrations of total and thermotolerant coliforms and this parameter was found $(\mathrm{r}=0.19$ for total, $r=0.09$ for thermotolerant coliforms) (Table 2).

There was a positive correlation between densities of total coliforms and rainfall rates $(\mathrm{r}=0.36)$. Thermotolerant coliforms $(\mathrm{r}=0.28)$ increased in relation to rainfall (Table 2). There was correlation between temperature and rainfall, temperature and salinity, and temperature and $\mathrm{pH}$.

Linear correlation between the environmental data, the total and thermotolerant coliforms and inter-tidal (neap and spring) was found by principal component analysis (PCA) (Figure 4). Component I accounted for $60.28 \%$ of the variance, negatively correlating levels of total and thermotolerant coliforms to the spring and neap tides, showing a significant difference between rates of coliforms for the different tides. The second component (II) represented $34.78 \%$ of variation, showing a positive relationship between rainfall and temperature, and a negative relationship with salinity and $\mathrm{pH}$. There was a negative correlation between the indices of total and thermotolerant coliforms with salinity in both tides. There was also a positive correlation between rainfall and the concentration of total and thermotolerant coliforms.

The high levels of thermotolerant coliforms observed in Itapitangui may be related to rainfall which preceded the sampling, which carried sediments and organic material from the continent. Galvão et al. (2006) argues that high levels of rainfall contribute to the increase of bacterial count in water for cultivation.

Oliveira \& Pinhata (2008) reported that proximity to the coast means that waters are subject to contamination by illegal sewage discharge and by urban drainage waters, considered to be the main causes of contamination of coastal waters, especially after rainy periods.

The high coliform concentrations found in Cooperostra are possibly related to the proximity of the Porto Cubatão district, where poor sanitation is a permanent source of pollution of the estuary by organic waste and domestic sewage. This area is next

Pesq. agropec. bras., Brasília, v.48, n.8, p.833-840, ago. 2013 DOI: 10.1590/S0100-204X2013000800004 
to the source responsible for the discharge of $50 \%$ of domestic sewage from Cananeia, which receives only a primary treatment, in which a large proportion of microorganisms is not eliminated. Machado et al. (2000), in studies to assess water quality as an input for extraction, management and cultivation of oysters in Porto Cubatão, Cananeia, found significant levels of contamination in this area. Barbieri \& Machado (2006) found that, in Cooperostra, in all studied months, most of the values for thermotolerant coliforms were higher than the one allowed by law. In the present study, the Itapitangui and Cooperostra samples exceeded the permissible values by Conama's Resolution 357/2005, during a few months, but the geometric mean remained within the allowable limits.

Ristori et al. (2007) evaluated the level of pathogenic bacteria in the oyster Crassostrea rizophorae (Guilding, 1828) and estuarine water in the southern coast of Brazil, and observed the presence of thermotolerant coliforms in $60 \%$ of water samples; in oysters, 80,70 and $10 \%$ of samples were contaminated by Vibrio vulnificus, Aeromonas sp. and Salmonella sp., respectively. Coliforms were detected in $40 \%$ of the treated oysters, suggesting a significant risk of the presence of pathogenic microorganisms in these mollusks.

Barros et al. (2005) showed a high percentage of thermotolerant coliforms in oysters marketed in Praia do Futuro, in Ceará state, Brazil, and the densities of thermotolerant coliforms in collected oysters ranged from 4 to $930 \mathrm{MPN} \mathrm{g}^{-1}$ and 4 to $430 \mathrm{MPN} \mathrm{g}^{-1}$ at two sampling points, suggesting that the low microbiological quality of mollusks is probably due to the high level of contamination in the aquatic environment of the region.

However, a study by Martinez \& Oliveira (2010) obtained bacterial densities in mussel flesh from 50 to 4,300 times greater than in water sampled in the vicinity of the mussels, which indicated that the relationship between the number of bacteria in the water and the bacteria accumulated by the mollusks is not straightforward and depends on many, difficult to evaluate, factors. Bacterial densities found in mussels are the result of complex interactions related to their physiology and morphology, such as size, filtering, excretion, and metabolic rates (Solé et al., 2000), and also depend on prey characteristics, such as size, specific composition and density of bacteria in the water. These latter are affected by several environmental conditions, such as solar irradiation, temperature, salinity, and nutrient availability (Sinton et al., 2002).

Mendes (2001), in studies on microbiological contamination of oysters consumed in greater Recife, Pernambuco state, Brazil, reported that the rate of contamination of water cultivation is dependent on seasonal changes. The authors noted that, in the summer, coliform densities were significantly lower, probably due to increased salinity as a result of increased tidal effects. Ristori et al. (2007), in studies in Cananeia, observed an increase of thermotolerant coliforms in the summer. In the present study, the highest values of total coliforms were observed in the summer and autumn, and the highest values of thermotolerant coliforms were observed during spring and summer. This occurred possibly because of the high rainfall recorded in the region, and also due to the increase of tourists in the region.

Kolm \& Andretta (2003) also observed the occurrence of higher densities of bacteria in the water of Perequê's stream, in Pontal do Sul, PR, in months with higher precipitation, which, however, for that region was the month of July.

When exposed to seawater, bacteria lose the capacity to grow because they are immediately confronted with multiple stressors, including salinity, that are not found in their natural habitats (Rozen \& Belkin, 2001). When there is contact between enteric bacteria and sea water, there is immediate osmotic shock, which can be overcome by the osmoregulatory systems of the microorganisms, increasing the survival rate of these bacteria in the marine environment (Gauthier et al., 1987; Munro et al., 1989). Thus, there is an effect of salinity on the survival of enteric bacteria, although yet it is less significant than expected. Craig et al. (2004) reported that coliform bacteria have little tolerance to high salinity, and concluded that the detection of coliforms in the environment is indicative of a steady discharge of fecal material.

Kolm et al. (2002) found no correlation between $\mathrm{pH}$ and coliform MPN in water, and Scott et al. (2003) found no correlation of temperature and $\mathrm{pH}$ with water contamination levels. Galvão et al. (2006), when studying the microbiological quality of water and mussel cultivation in Ubatuba, SP, Brazil, found evidence of microbiological contamination in the water and the mussels, but these values had no relationships with $\mathrm{pH}$. Variations in $\mathrm{pH}$ may be related to the tides, 
and Kolm \& Andretta (2003) reported that, during high tides, the change in $\mathrm{pH}$ was significantly higher than during low tides.

During the present study, temperature was not correlated with the concentration of coliforms; however, some parameters, such as temperature, rainfall, salinity and $\mathrm{pH}$ were correlated, showing that there may be synergistic or antagonistic interactions that affect coliform concentrations. Estuarine environments are subject to constant environmental changes that depend on meteorological and hydrological conditions, and are also susceptible to human influence that can change environmental characteristics. Kolm et al. (2002) assessed environmental variables with bacterial biomass in Paranaguá Bay and Antonina, PR, Brazil, and established the existence of a direct relationship between salinity and water transparency, and a negative relationship with organic matter, bacterial biomass and total coliforms; these authors concluded that human influence can directly or indirectly change the environmental characteristics of coastal regions.

Based on Conama 357/2005, the results of the present research indicate that the area of Mandira proved to be suitable for oyster cultivation, because coliform levels, in almost all samples, were within the established limits. In Cooperostra, most samples were within the permissible limits, but there is a need for constant water monitoring. In Itapitangui, the levels of thermotolerant coliform exceeded the permissible values in some samples, but the calculated geometric mean was within the limits.

The contamination of waters and environmental degradation may also harm the economy of coastal cities, and negatively affect tourism and compromise fisheries (Collins et al., 1998). In this context, monitoring the pollution of coastal sea waters by chemical and microbiological pollutants is a highly important task (Oliveira et al., 2008, 2010; Barbieri \& Doi, 2011; Barbieri \& Paes, 2011).

These results may suggest that a simple diagnosis of the environmental conditions of cultivation fields is insufficient to assess water quality of shellfish cultivation, due to fluctuations in the levels of contamination throughout the year, and because contaminants accumulate in marine biota, especially filtering organisms such as mussels. Thus, a program of continuous monitoring of cultivation areas would be suitable not only for assessing the potential of these for marine culture and for ensuring the safe consumption of seafood, but also for the understanding of the relationships between contamination and environmental variables.

\section{Conclusions}

1. There is a negative correlation between salinity and total and thermotolerant coliform levels.

2. The highest geometric means of total and thermotolerant coliforms are recorded during the neap tide.

3. An increase in thermotolerant coliform is observed in the summer.

4. A simple diagnosis of environmental conditions of the crop fields is insufficient to assess the water quality of shellfish cultivation.

5. A program continuous monitoring of cultivation areas is necessary for assessing their potential for marine culture, and for ensuring the safe consumption of seafood.

\section{Acknowledgements}

To Fundação de Amparo à Pesquisa do Estado de São Paulo (Fapesp registry number 2012/50184-8) and to Conselho Nacional de Desenvolvimento Científico e Tecnológico (CNPq registry number 308700/2010-4), for their financial support.

\section{References}

AMERICAN PUBLIC HEALTH ASSOCIATION. Standard methods for the examination of water and wastewater. $21^{\text {th }}$ ed. Washington: APHA, 2005. 1120p.

BARBIERI, E.; DOI, S.A. The effects of different temperature and salinity levels on the acute toxicity of zinc in the pink shrimp (Farfantepenaeus paulensis). Marine and Freshwater Behaviour and Physiology, v.44, p.251-263, 2011. DOI: 10.1080/10236244.2011.617606.

BARBIERI, E.; MACHADO, I.C. Qualidade microbiológica da água de cultivo de ostra (Crassostrea brasiliana) comercializada em Cananéia, SP (Brasil). In: CONGRESO IBEROAMERICANO VIRTUAL DE ACUICUlTURA, 4., 2006. Proceedings. [S.1.]: Sociedad Española de Acuicultura, 2006. p.1-8.

BARBIERI, E.; PAES, E.T. The use of oxygen consumption and ammonium excretion to evaluate the toxicity of cadmium on Farfantepenaeus paulensis with respect to salinity. Chemosphere, v.8, p.9-16, 2011. DOI: 10.1016/j.chemosphere.2011.02.092.

Pesq. agropec. bras., Brasília, v.48, n.8, p.833-840, ago. 2013 DOI: 10.1590/S0100-204X2013000800004 
BARROS, L.M. de O.; THEOPHILO, G.N.D.; COSTA, R.N.; RODRIGUES, D. dos P.; VIEIRA, R.H.S. dos F. Contaminante fecal da ostra Crassostrea rhizophorae comercializada na Praia do Futuro, Fortaleza, Ceará. Revista Ciência Agronômica, v.36, p.285-289, 2005.

COLLINS, A.; STAPLETON, M.; WHITMARSH, D. Fishery-pollution interactions: a modelling approach to explore the nature and incidence of economic damages. Marine Pollution Bulletin, v.36, p.211-221, 1998. DOI: 10.1016/ S0025-326X(97)00193-8.

CRAIG, D.L.; FALLOWFIELD, H.J.; CROMAR, N.J. Use of microcosms to determine persistence of Escherichia coli in recreational coastal water and sediment and validation with in situ measurements. Journal of Applied Microbiology, v.96, p.922-930, 2004. DOI: 10.1111/j.1365-2672.2004.02243.x

DAME, R.F. Organism level processes. In: DAME, R.F. Ecology of marine bivalves: an ecosystem approach. New York: CRC, 1996. p.35-74. DOI: $10.1201 / 9781420049787$.

EFSTRATIOU, M.A. Managing coastal bathing water quality: the contribution of microbiology and epidemiology. Marine Pollution Bulletin, v.42, p.425-432, 2001. DOI: 10.1016/ S0025-326X(00)00225-3.

GALVÃO, J.A.; FURLAN, É.F.; SÁLAN, E. de O.; PORTO, E.; OETTERER, M. Características físico-químicas e microbiológicas (Staphylococcus aureus e Bacillus cereus) da água e dos mexilhões cultivados em Ubatuba, SP. Ciência e Agrotecnologia, v.30, p.1124-1129, 2006. DOI: 10.1590/S1413-70542006000600013.

GAUTHIER, M.J.; MUNRO, P.M.; MOHAJER, S. Influence of salts and sodium chloride on the recovery of Escherichia coli from seawater. Current Microbiology, v.15, p.5-10, 1987. DOI: 10.1007/BF01577205.

KOLM, H.E.; ANDRETTA, L. Bacterioplancton in different tides of the Perequê tidal creek, Pontal do Sul, Paraná, Brazil. Brazilian Journal of Microbiology, v.34, p.97-103, 2003. DOI: 10.1590/ S1517-83822003000200002.

KOLM, H.E.; SCHOENENBERGER, M.F.; PIEMONTE, M. da R.; SOUZA, P.S. de A.; SCÜHLI, G.S.; MUCCIATTO, M.B.; MAZZUCO, R. Spatial variation of bacteria in surface water of Paranaguá and Antonina Bays, Paraná, Brazil. Brazilian Archives of Biology and Technology, v.45, p.27-34, 2002. DOI: 10.1590/ S1516-89132002000100005.

MACHADO, I.C.; KOGA, S.M.; WOIOECHOVSKY, E.; GELLI, D.S. Estudo da ocorrência de contaminação orgânica no estuário de Cananeia-SP, Brasil, com subsídio para a extração, manejo e cultivo da ostra do mangue Crassostrea brasiliana: avaliação da qualidade da água. Revista Higiene Alimentar, v.14, p.66-75, 2000.

MARTINEZ, D.I.; OLIVEIRA, A.J.F.C. de. Faecal bacteria in Perna perna (Linnaeus, 1758) (Mollusca: Bivalvia) for biomonitoring coastal waters and seafood quality. Brazilian Journal of Oceanography, v.58, p.29-35, 2010. DOI: 10.1590/ S1679-87592010000700005.
MENDES, E.S. Avaliação microbiológica de ostras consumidas na grande Recife - PE. 2001. 102p. Tese (Doutorado) Universidade Estadual Paulista, Botucatu.

MUNRO, P.M.; GAUTHIER, M.J.; BREITTMAYER, V.A.; BONGIOVANNI, J. Influence of osmoregulation processes on starvation survival of Escherichia coli in seawater. Applied and Environmental Microbiology, v.55, p.2017-2024, 1989.

OLIVEIRA, A.J.F.C. de; FRANÇA, P.T.R. de; PINTO, A.B. Antimicrobial resistance of heterotrophic marine bacteria isolated from seawater and sands of recreational beaches with different organic pollution levels in Southeastern Brazil: evidences of resistance dissemination. Environmental Monitoring and Assessment, v.169, p.375-384, 2010. DOI: 10.1007/ s10661-009-1180-6.

OLIVEIRA, A.J.F.C. de; PINHATA, J.M.W. Antimicrobial resistance and species composition of Enterococcus spp. isolated from waters and sands of marine recreational beaches in Southeastern Brazil. Water Research, v.42, p.2242-2250, 2008. DOI: 10.1016/j.watres.2007.12.002.

RISTORI, C.A.; IARIA, S.T.; GELLI, D.S.; RIVERA, I.N.G. Pathogenic bacteria associated with oysters (Crassostrea brasiliana) and estuarine water along the south coast of Brazil. International Journal of Environmental Health Research, v.17, p.259-269, 2007. DOI: 10.1080/09603120701372169.

ROZEN, Y.; BELKIN, S. Survival of enteric bacteria in seawater. FEMS Microbiology Reviews, v.25, p.513-529, 2001. DOI: 10.1111/j.1574-6976.2001.tb00589.x.

SANTOS, E. Zoologia brasileira: moluscos do Brasil. Belo Horizonte: Itatiaia, 1982. 141p.

SCOTT, T.M.; PARVEEN, S.; PORTIER, K.M.; ROSE J.B.; TAMPLIN, M.L.; FARRAH, S.R.; KOO, A.; LUKASIK J. Geographical variation in ribotype profiles of Escherichia coli isolates from humans, swine, poultry, beef, and dairy cattle in Florida. Applied and Environmental Microbiology, v.69, p.1089-1092, 2003. DOI: 10.1128/AEM.69.2.1089-1092.2003.

SINTON, L.W.; HALL, C.H.; LYNCH, P.A.; DAVIES-COLLEY, R.J. Sunlight inactivation of fecal indicator bacteria and bacteriophages from waste stabilization pond effluent in fresh and saline waters. Applied and Environmental Microbiology, v.68, p.1122-1131, 2002. DOI: 10.1128/AEM.68.3.1122-1131.2002.

SOLÉ, M.; PORTE, C.; BARCELO, D.; ALBAIGES J. Bivalves residue analysis for the assessment of coastal pollution in the Ebro Delta (NW Mediterranean). Marine Pollution Bulletin, v.40, p.746-753, 2000. DOI: 10.1016/S0025-326X(00)00011-4.

TOMMASI, L.R. A degradação do meio ambiente. São Paulo: Edusp, 1979. 169p.

WORLD HEALTH ORGANIZATION. Guidelines for safe recreational water environments. Volume 1: coastal and fresh waters. Geneva: World Health Organization, 1998. 219p.

ZAR, J.H. Biostatistical analysis. $5^{\text {th }}$ ed. New Jersey: Prentice-Hall, 2009. 789p.

Received on June 14, 2011 and accepted on July 15, 2013

Pesq. agropec. bras., Brasília, v.48, n.8, p.833-840, ago. 2013

DOI: $10.1590 / \mathrm{S} 0100-204 X 2013000800004$ 